Journal of Environmental Sciences (JES)

Faculty of Graduate Studies and Environmental Research, Ain Shams University

El-Sharkawy et al.

\title{
DESALINATION OF SALINE WATER USING SOLAR THERMAL ENERGY FOR THE PRODUCTION OF CULTURED BARLEY
}

\author{
Khaled M. El-Sharkawy ${ }^{(1)}$; Hisham I. El-kassas ${ }^{(2)}$ \\ and Hany E. Abdel Halem ${ }^{(3)}$
}

1) Armed forces 2) Faculty of Graduate Studies and Environmental Research, Ain Shams University. 3) Faculty of Engineering, Ain Shams University

\begin{abstract}
In the last decades more countries have experienced water scarcity problems thus pointing at alternative non-conventional sources of fresh water. Sea water desalination has proven to be a reliable and economically sustainable water resource since the second half of the $20^{\text {th }}$ century. The direct solar radiation and solar energy concentrator (Solar Parabolic Trough (SPT) was used in this study. Parabolic-Trough Collector (PTC) is a linearfocus solar collector, basically composed of a parabolic-trough-shaped concentrator that reflects direct solar radiation onto a receiver or absorber tube located at the focal line of the parabola. The Parabolic Trough is tracking the sun using simple mechanism to collect the highest amount of solar radiation by optimum angle. Representative samples of saline water from ElTamsah lake in Ismailia, the Mediterranean sea at Alexandria and the Red sea at Ain sokhna with salinity $31680 \mathrm{mg} \mathrm{L}^{-1}, 33920 \mathrm{mg} \mathrm{L}^{-1}$ and $36480 \mathrm{mg} \mathrm{L}^{-1}$ respectively after treatment with PTC, the salt concentration at El-Tamsah lake sample was $326 \mathrm{mg} \mathrm{L}^{-1}$, while at Alexandria sample was $1036 \mathrm{mg} \mathrm{L}^{-1}$ and at Ain sokhna sample was $652.8 \mathrm{mg} \mathrm{L}^{-1}$.

The results showed that the removal \% of salts from El-Tamsah lake sample was $98.9 \%$, from Alexandria sample was $96.9 \%$ and from Ain sokhna sample was $98.2 \%$. The result showed that the physical and chemical properties of saline water after treatment became suitable for agricultural cultured barely used in production as green fodder.
\end{abstract}


Journal of Environmental Sciences (JES)

Faculty of Graduate Studies and Environmental Research, Ain Shams University

El-Sharkawy et al.

Keywords: Parabolic Trough Concentrator, Water Desalination, Solar Thermal Energy, Heat Transfer Fluid, Electric Conduction.

\section{INTRODUCTION}

The River Nile is the backbone of Egypt's primary source of drinking water for the population. Egypt is facing an annual water deficit of around 7 billion cubic meters. Egypt's population is mushrooming at alarming rate and has increased by $41 \%$ since the early 1990s. Recent reports by the government suggested that around 4700 newborns are added to population every week, and future projections said that the population grows to 110 million by 2025 . The rapid population increase multiplies the stress on Egypt's water supply due to more water requirements to domestic consumption and increased use of irrigation water to meet higher food demands (Dakkak et al., 2020).

Parabolic-Trough Collector (PTC) is a mature solar thermal technology and is used widely for various industrial heating application and is very useful while working below $400{ }^{\circ} \mathrm{C}$. PTC comprises of a mirror finish curved glass plate bent into parabolic shape so as to linearly focus all the incident radiation onto the absorber tube. In some large applications, many of such sheets are put together to form a long arrays of troughs. The receiver/absorber system which is typically a metal pipe enclosed in an evacuated glass tube (to reduce the convection losses), is mounted on the focus of the collector. To increase the thermal effectiveness and minimize the losses, anti-reflective coating is also applied on metal pipe (Singh et al., 2017).

498

Vol. (50); Iss. (11); No.(7); Nov. 2021

ISSN 1110-0826

ONLINE ISSN 2636 - 3178 
Journal of Environmental Sciences (JES)

Faculty of Graduate Studies and Environmental Research, Ain Shams University

El-Sharkawy et al.

Primarily, the function of the collector is to focus the incident solar radiations onto the receiver/absorber system which is a heat exchanger device from where heat is carried away by Heat Transfer Fluid (HTF), which is one of the critical constituent for the overall performance of the PTC. Most suitable characteristics of the HTF includes thermal stability, high boiling point, high thermal conductivity, low melting point, high specific heat capacity for energy storage purpose and low viscosity. Depending on the working temperature and end use, suitable HTF is used. HTF's could be assorted into six groups namely air or other gases; water/steam; Thermal oil; organics; molten-salts; liquid metals. Different researchers has used different types of materials for heat absorbing tube, such as copper, stainless steel, brass, etc. along with different type of absorbing fluid materials such as Nano fluid, thermal oil, molten salt, water, air (Singh et al., 2017).

The aim of this study is to develop small-scale solar desalination technology by using manufacturing materials from the local market to manufacture and assemble the solar power plant (Parabolic Trough) for desalination of saline water and the production of pure water that can be used in the production of cultured barley.

\section{MATERIALS AND METHODS}

Parabolic Trough Concentrator: The Parabolic troughs are long (linear) collectors. Its reflector surface focuses of sunlight to a receiver tube located along the focal line, heating the heat transfer fluid in the tube. Parabolic 
Journal of Environmental Sciences (JES)

Faculty of Graduate Studies and Environmental Research, Ain Shams University

El-Sharkawy et al.

troughs typically have concentrations of 10 to 100 times, resulting in operating temperatures ranging from 100 to $400^{\circ} \mathrm{C}$. The Parabolic troughs collector comprises of a mirror finish curved glass plate bent into parabolic shape which leads to linearly focus all the incident radiation onto the absorber tube. The receiver/absorber system which is typically a metal pipe enclosed in an evacuated glass tube to reduce the convection losses, is mounted on the focus of the collector. To increase the thermal effectiveness and minimize the losses, anti-reflective coating (Singh et al., 2017).

PTCs require tracking sunlight along the axis and/or axes only. In this way, the receiving tube can achieve high temperature. PTCs systems usually include a mechanical control system that keeps the reflector reflective on the sun throughout the day. These systems can provide hot water and steam, commonly used in commercial and industrial applications However, among solar thermal techniques, PTCs systems are the best used for desalination. Due to high temperatures, parabolic troughs can produce high-quality thermal energy and are generally used to produce electricity.

Tested design of parabolic trough collectors: Parabolic trough collectors are employed in a variety of applications, including industrial steam and water production. The locally made parabolic through solar energy concentrator consists of the following components: reflector surface, reflector frame support, absorber pipe, and stands. All were fabricated using locally sourced materials will be described as follows: 
Journal of Environmental Sciences (JES)

Faculty of Graduate Studies and Environmental Research, Ain Shams University

El-Sharkawy et al.

Table (1): The locally made parabolic concentrator

\begin{tabular}{|c|c|c|}
\hline No. & Component & Dimension \\
\hline 1 & $\begin{array}{c}\text { Mirror material Black silvered glass, 2mm } \\
\text { thickness }\end{array}$ & $1.5 \mathrm{~m} \mathrm{x} 1.21 \mathrm{~m}$ \\
\hline 2 & PTC Frame Wood & $1.12 \mathrm{~m}$ \\
\hline 3 & Wooden base & $1.5 \mathrm{~m} \times 1.12$ \\
\hline 4 & Copper tube & $1.5 \mathrm{~m}$ \\
\hline 5 & Glass cover tube & $1.5 \mathrm{~m}$ \\
\hline 6 & Base assembly & -- \\
\hline 7 & Mirror on wooden base & -- \\
\hline 8 & PTC assembly & $\mathrm{m}$ \\
\hline
\end{tabular}

Heat transfer fluid: The Heat Transfer Fluid (HTF) accumulates the thermal energy in the collectors and transports it to the power block, a heat transfer fluid cycle between mineral oil and the saline water cycle. The mineral oil is heated as a result of exposure to the heat collected in the solar collector, and then it moves in its closed cycle until it connects with saline water tank the thermal connection zone between them realize a steam. The mineral oil cycle runs through an electric pump. HTF Requirements (mineral oil) with High evaporation temperature, High operating temperatures $\left(>400^{\circ} \mathrm{C}\right)$, Low freezing temperature (near room temperature), low vapor pressures at high temperatures, have high thermal conductivity, high volumetric heat capacity and Thermal stability. Based on this we choose Shell S2 Heat Transfer Oil (Lenert, A., et al 2012). 


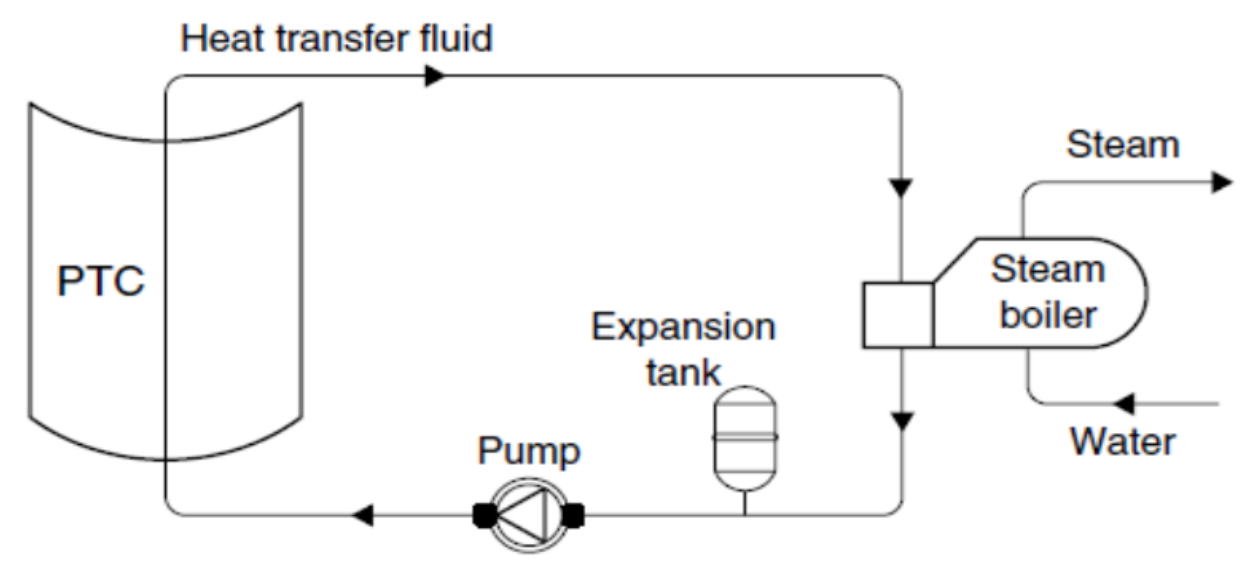

Fig. (1): Parabolic Trough Concentrator (PTC) model for water distillation (Kalogirou, 2014)

Thermal Analysis of Parabolic Trough Collectors (Duffie et al., 2013):

The Area:

$$
\mathrm{A}=\pi \mathrm{D}_{\mathrm{o}} \mathrm{L} \rightarrow
$$

The receiver area $A_{r}$

The glass cover area $\mathrm{Ag}_{\mathrm{g}}$

The unshaded collector aperture area $\mathrm{A}_{\mathrm{a}}$

The glass cover temperature:

$T_{a v}=\left(T_{g}+T_{a}\right) / 2 \rightarrow \quad 2$

The Reynolds number can be estimated: $\quad \operatorname{Re}=\rho \mathrm{VD}_{\mathrm{g}} / \mu \rightarrow \quad 3$

The Nusselt number $(\mathrm{Nu})$ can be estimated: $\quad N u=0.3(R e)^{0.6} \rightarrow 4$

The convective (wind) heat transfer coefficient $\rightarrow h_{c,-a}=h_{w}$

$$
h_{c,-a}=h_{w}=\left(N_{u}\right) k / D_{c} \rightarrow
$$

The radiation heat transfer coefficient $h_{r, \mathrm{c}-a}$ can be estimated: $*(\mathrm{~T} \rightarrow \mathrm{K})$

$$
h_{r, \mathrm{c}-a}=\varepsilon_{\mathrm{g}} \sigma\left(T_{C}+T_{a}\right)\left(T_{c^{2}}+T_{a}^{2}\right) \rightarrow 6
$$


The radiation heat transfer co-efficient, between the receiver tube and the glass cover $\boldsymbol{h}_{\boldsymbol{r},-\boldsymbol{c}}$ :

$$
\boldsymbol{h}_{\boldsymbol{r}, \mathrm{r}-\boldsymbol{c}=} \frac{\sigma\left(\mathrm{T}_{\mathrm{c}}{ }^{2}+\mathrm{T}_{\mathrm{c}}{ }^{\mathrm{z}}\right)\left(\mathrm{T}_{\mathrm{r}}+\mathrm{T}_{\mathrm{c}}\right)}{\frac{1}{\mathrm{v}_{\mathrm{r}}}+\frac{\mathrm{A}_{\mathrm{r}}}{\mathrm{A}_{\mathrm{c}}}\left[\frac{1}{\mathrm{v}_{\mathrm{c}}}-1\right]} \rightarrow 7
$$

The space between the receiver and the glass cover is evacuated, so there is no convection heat transfer.

Solar Collector overall heat loss coefficient can be estimated as follows:

$$
\mathrm{U}_{\mathrm{L}}=\left[\frac{\mathrm{A}_{\mathrm{T}}}{\left(\mathrm{h}_{\mathrm{W}}+\mathrm{h}_{\mathrm{T}_{\mathrm{i}} \mathrm{C}-\mathrm{g}}\right) A_{\mathrm{e}}}+\frac{1}{\mathrm{~h}_{\mathrm{T}, \mathrm{r}-\mathrm{e}}}\right]^{-1} \rightarrow \quad 8
$$

Since $U_{L}$ is based on the assumed $T_{g}$ value we need to check if the assumption made was correct $\mathrm{T}_{\mathrm{g}}$ can be estimated as follows:

$$
\mathrm{T}_{\mathrm{g}}=\left[\frac{\mathrm{A}_{\mathrm{T}} \mathrm{h}_{\mathrm{r}, \mathrm{r}-\mathrm{c}} \mathrm{T}_{\mathrm{r}}+\mathrm{A}_{\mathrm{g}}\left(\mathrm{h}_{\mathrm{W}}+\mathrm{h}_{\mathrm{T}, \mathrm{c}-\mathrm{g}}\right) \mathrm{T}_{\mathrm{a}}}{\mathrm{A}_{\mathrm{T}} \mathrm{h}_{\mathrm{T}_{\mathrm{I}} \mathrm{r}-\mathrm{c}}+\mathrm{A}_{\mathrm{g}}\left(\mathrm{h}_{\mathrm{W}}+\mathrm{h}_{\mathrm{r}_{\mathrm{u}} \mathrm{C}-\mathrm{g}}\right)}\right] \quad \rightarrow \quad 9
$$

Collector efficiency factor $F^{\prime}$ can be estimated as follows:

$$
F^{\prime}=\frac{\frac{1}{\mathbb{W}_{\mathrm{L}}}}{\frac{1}{\mathbb{U}_{\mathrm{L}}}+\frac{\mathrm{D}_{0}}{\mathrm{~h}_{\mathrm{fi}} \mathrm{D}_{\mathrm{i}}}+\left[\frac{\mathrm{D}_{0}}{\mathrm{v} k} \operatorname{In} \frac{\mathrm{D}_{0}}{\mathrm{D}_{\mathrm{i}}}\right]} \rightarrow
$$

The heat removal factor $F_{R}$ can be estimated:

$$
\mathrm{F}_{\mathrm{R}}=\frac{\mathrm{mc}_{\mathrm{p}}}{\mathrm{A}_{\mathrm{r}} \mathrm{U}_{\mathrm{L}}}\left[1-\exp \left(-\frac{\mathrm{U}_{\mathrm{L}} F^{\prime} \mathrm{A}_{\mathrm{r}}}{\mathrm{mc}_{\mathrm{p}}}\right)\right] \rightarrow
$$

The useful energy $Q_{u}$ can be estimated as follows:

$\mathrm{Q}_{\mathrm{u}}=\mathrm{F}_{\mathrm{r}}\left[\mathrm{S} \mathrm{A}_{\mathrm{a}}-\mathrm{A}_{\mathrm{r}} \mathrm{U}_{\mathrm{L}}\left(\mathrm{T}_{\mathrm{i}}-\mathrm{T}_{\mathrm{a}}\right)\right]$

Finally the exit temperature can be estimated as follows:

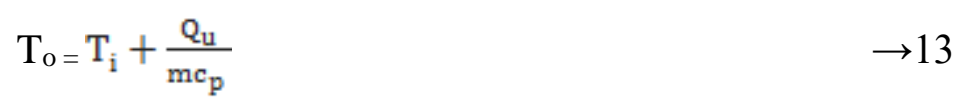


Quantity of evaporated water

$\mathrm{Q}_{\text {oil }}=\mathrm{Q}_{\text {water }} \rightarrow$

$\mathrm{Q}=\mathrm{M}_{\mathrm{S}} \mathrm{C}_{\mathrm{P}}\left(\mathrm{T}_{\text {OUT }}-\mathrm{T}_{\mathrm{IN}}\right) \rightarrow$ for oil $\rightarrow 2$

$\mathrm{M}_{\mathrm{S}}=\mathrm{V} \rho$

$\mathrm{Q}=\mathrm{M}_{\mathrm{S}} \mathrm{C}_{\mathrm{P}}\left(\mathrm{T}_{\text {OUT }}-\mathrm{T}_{\mathrm{IN}}\right) \rightarrow$ for water $\rightarrow 3$

Apply the device economically: Through the recorded readings of the intensity of the sun's radiation throughout the year and through the mathematical equations of the parabolic device that can be applied to an economic model 20 long parabolic trough collector with an aperture width of $3.5 \mathrm{~m}$. The economic model gives better results in terms of the amount of water produced.

The main objective of the research is to desalinate saline water and changed it to the fresh water specification that is used in agriculture. Therefore, the study suggested this water can be used by default in the production of agricultural crops with small water Requirements, such as green fodder from cultured barley. The results of a study carried out by Safina, (2018) were Suppose the possibility of producing cultured barley to clarify that it is possible to use this desalinated water in future plans for agricultural development. Scientific name of Barley is hordeum vulgare, variety (Giza126), cultivation period (7 days), in Hydroponics, total quantities of water used for irrigation (400 liter for one ton), cultivated area $\left(50 \mathrm{~m}^{2}\right)$. (Safina, 2018) 
Journal of Environmental Sciences (JES)

Faculty of Graduate Studies and Environmental Research, Ain Shams University

El-Sharkawy et al.

\section{SAMPLES}

- The samples were taken from El-Tamsah Lake in Ismailia, the Mediterranean sea in Alexandria and the Red sea in Ain sokhna. The samples were collected in polyethylene (PE) bottles treated with acid wash and rinsed using reagent water (Eaton, et. al., 1995). Chemical analyses of the collected samples were carried at Desert Research Center.

- Water acidity (pH) of water was measured according to (Jackson 1967).

- Electrical Conductivity (EC) in desalinized water was measured according to United States Department of Agriculture (1969).

- Determination of water ions (cations and anions) in desalinized water was made according to the methods described by Black (1965). 
Faculty of Graduate Studies and Environmental Research, Ain Shams University

El-Sharkawy et al.

\section{RESULTS AND DISCUSSION}

\section{Water desalination and quantity}

Table (2): Water desalination analyses in El-Tamsah Lake water at Ismailia

\begin{tabular}{|c|c|c|c|c|c|c|c|}
\hline Latitude & $\begin{array}{c}\text { Solar } \\
\text { radiation } \\
\mathrm{Wh} / \mathrm{m}^{2}\end{array}$ & & $\begin{array}{c}\text { Exit } \\
\text { temperature } \\
\mathrm{C}^{\circ}\end{array}$ & $\begin{array}{c}\text { Water } \\
\text { production } \\
\mathrm{L} / 1 \mathrm{~m}\end{array}$ & $\begin{array}{c}\text { Water } \\
\text { production } \\
\mathrm{L} / 1 \mathrm{~h}\end{array}$ & $\begin{array}{c}\text { Water } \\
\text { production } \\
\mathrm{L} / 5 \mathrm{~h}\end{array}$ & $\begin{array}{c}\text { Water } \\
\text { production } \\
\mathrm{L} / 10 \mathrm{~h}\end{array}$ \\
\hline 30 & 350 & & 252 & 4.86 & 292 & 1460 & 2920 \\
\hline \multicolumn{8}{|c|}{ Water desalination analyses } \\
\hline \multirow{2}{*}{\multicolumn{3}{|c|}{$\mathrm{EC}\left(\mathrm{ds} \mathrm{\textrm {m } ^ { - 1 } )}\right.$}} & \multicolumn{2}{|c|}{ Before } & \multicolumn{3}{|c|}{ After } \\
\hline & & & \multicolumn{2}{|c|}{49.5} & \multicolumn{3}{|c|}{0.51} \\
\hline \multicolumn{3}{|c|}{$\mathrm{mg} \mathrm{L}^{-1}$} & \multicolumn{2}{|c|}{31680} & \multicolumn{3}{|c|}{326} \\
\hline \multicolumn{3}{|c|}{ Removal percentage } & \multicolumn{5}{|c|}{$98.9 \%$} \\
\hline \multirow{8}{*}{ 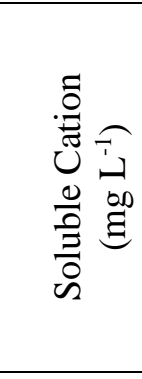 } & \multirow{2}{*}{\multicolumn{2}{|c|}{$\mathrm{Ca}^{2-}$}} & 212 & & & 0.45 & \\
\hline & & & \multicolumn{5}{|c|}{ Removal percentage $99.97 \%$} \\
\hline & \multirow{2}{*}{\multicolumn{2}{|c|}{$\mathrm{Mg}^{2-}$}} & 140 & & & 0.22 & \\
\hline & & & \multicolumn{5}{|c|}{ Removal percentage $99.84 \%$} \\
\hline & \multirow{2}{*}{\multicolumn{2}{|c|}{$\mathrm{Na}^{+}$}} & 330 & & & 4.32 & \\
\hline & & & \multicolumn{5}{|c|}{ Removal percentage $98.69 \%$} \\
\hline & \multirow{2}{*}{\multicolumn{2}{|c|}{$\mathrm{K}^{+}$}} & 9.8 & & & 0.11 & \\
\hline & & & \multicolumn{5}{|c|}{ Removal percentage $98.87 \%$} \\
\hline \multirow{6}{*}{ 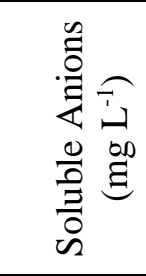 } & \multirow{2}{*}{\multicolumn{2}{|c|}{$\mathrm{HCO}_{3}^{-}$}} & 31. & & & 0.41 & \\
\hline & & & \multicolumn{5}{|c|}{ Removal percentage $98.7 \%$} \\
\hline & \multirow{2}{*}{\multicolumn{2}{|c|}{$\mathrm{CL}^{-}$}} & 463 & & & 3.97 & \\
\hline & & & \multicolumn{5}{|c|}{ Removal percentage $99.14 \%$} \\
\hline & \multirow{2}{*}{\multicolumn{2}{|c|}{$\mathrm{SO}_{4}^{-}$}} & 198 & & & 0.72 & \\
\hline & & & \multicolumn{5}{|c|}{ Removal percentage $99.63 \%$} \\
\hline
\end{tabular}

* The amount of water collected was 1.5 L during February 2019.

$* \mathrm{Wh} / \mathrm{m}^{2}=$ watt hour/ square meter

$*_{\mathrm{L} /} 1 \mathrm{~min}=$ liter/ minute

$* \mathrm{~L} / \mathrm{h}=$ liter/ hour

*EC $($ Electric Conduction Coefficient $)=$ mhos $/ \mathrm{cm}$ 
Journal of Environmental Sciences (JES)

Faculty of Graduate Studies and Environmental Research, Ain Shams University

El-Sharkawy et al.

Studying the data from (STDF, 2017) for solar radiation. The treatment was carried out in Cairo at latitude 30 at Abbasia, Faculty of Engineering, Ain Sims University, during the month of February and the average solar radiation was $350 \mathrm{Wh} / \mathrm{m}^{2}$ in February, as well as the amount of water produced from the treatment procedure was calculated by using the economic type and through mathematical equations. The amount of water recorded in the first minute of operation at a temperature $252^{\circ} \mathrm{C}$ was 4.86 liter. After one hour of operation it was 292 liters, and at the end of day (after 10 hour) it was 2920 liters.

According to Table (2), The water of Lake Al-Temsah is considered to be highly saline water according to FAO classification (FAO, 1992). The Total concentration of salts was $31680 \mathrm{mg} \mathrm{L}^{-1}$ and the Electric Conduction Coefficient (EC) 49.5. Therefore, water is not suitable for use in any of the human activities. The process of treatment on this sample using solar thermal technology was the result of the process of salt removal to $98.9 \%$ as the total concentration of salts has decreased to $326 \mathrm{mg} \mathrm{L}^{-1}$, which is non-saline water according to the classification of FAO, and the electrical conductivity coefficient value decreased to 0.51 and the sample became usable in various human activities. It was also noted that sodium cations decreased to $98.6 \%$, before the treatment was $330.79 \mathrm{mg} \mathrm{L}^{-1}$ and then became $4.32 \mathrm{mg} \mathrm{L}^{-1}$. 
Journal of Environmental Sciences (JES)

Faculty of Graduate Studies and Environmental Research, Ain Shams University

El-Sharkawy et al.

Table (3): Water desalination analyses in Mediterranean Sea in Alexandria April 2019 -1.5 L

\begin{tabular}{|c|c|c|c|c|c|c|c|}
\hline Latitude & $\begin{array}{c}\text { Solar } \\
\text { radiation } \\
\mathrm{Wh} / \mathrm{m}^{2} \\
\end{array}$ & $\begin{array}{c}\text { Useful } \\
\text { energy } \\
\text { w }\end{array}$ & $\begin{array}{c}\text { Exit } \\
\text { temperature } \\
\mathrm{C}^{\mathrm{o}}\end{array}$ & $\begin{array}{c}\text { Water } \\
\text { production } \\
\mathrm{L} / 1 \mathrm{~m}\end{array}$ & $\begin{array}{c}\text { Water } \\
\text { production } \\
\mathrm{L} / 1 \mathrm{~h}\end{array}$ & $\begin{array}{c}\text { Water } \\
\text { production } \\
\mathrm{L} / 5 \mathrm{~h}\end{array}$ & $\begin{array}{c}\text { Water } \\
\text { production } \\
\mathrm{L} / 10 \mathrm{~h}\end{array}$ \\
\hline 30 & 650 & 32216 & 294 & 6.9 & 414 & 2070 & 4140 \\
\hline \multicolumn{8}{|c|}{ Water desalination analyses } \\
\hline & & & \multicolumn{2}{|c|}{ Before } & \multicolumn{3}{|c|}{ After } \\
\hline \multicolumn{2}{|c|}{$\mathrm{EC}\left(\mathrm{ds} \mathrm{m}^{-1}\right)$} & & \multicolumn{2}{|c|}{55} & \multicolumn{3}{|c|}{1.62} \\
\hline \multicolumn{2}{|c|}{$\mathrm{mg} \mathrm{L}^{-1}$} & & \multicolumn{2}{|c|}{33920} & \multicolumn{3}{|c|}{1036} \\
\hline \multicolumn{3}{|c|}{$\begin{array}{c}\text { Removal } \\
\text { percentage }\end{array}$} & \multicolumn{5}{|c|}{$96.9 \%$} \\
\hline \multirow{8}{*}{ 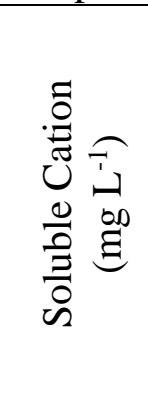 } & \multirow{2}{*}{$\mathrm{Ca}^{2-}$} & & 216. & & & 4.49 & \\
\hline & & & \multicolumn{3}{|c|}{ Removal percentage } & $98.27 \%$ & \\
\hline & \multirow{2}{*}{$\mathrm{Mg}^{2-}$} & & 67. & & & 2.42 & \\
\hline & & & \multicolumn{3}{|c|}{ Removal percentage } & $99.97 \%$ & \\
\hline & \multirow{2}{*}{$\mathrm{Na}^{+}$} & & 445 . & & & 8.88 & \\
\hline & & & \multicolumn{3}{|c|}{ Removal percentage } & $96.42 \%$ & \\
\hline & \multirow{2}{*}{\multicolumn{2}{|c|}{$\mathrm{K}^{+}$}} & 13. & & & 0.41 & \\
\hline & & & \multicolumn{3}{|c|}{ Removal percentage } & $97.04 \%$ & \\
\hline \multirow{6}{*}{ 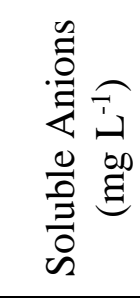 } & \multirow{2}{*}{$\mathrm{HCO}_{3}^{-}$} & & 154. & & & 2.59 & \\
\hline & & & \multicolumn{2}{|c|}{ Removal pe } & centage & $98.32 \%$ & \\
\hline & \multirow{2}{*}{$\mathrm{CL}^{-}$} & & 384. & & & 9.74 & \\
\hline & & & \multicolumn{3}{|c|}{ Removal percentage } & $97.46 \%$ & \\
\hline & \multirow{2}{*}{$\mathrm{SO}_{4}^{-}$} & & 203. & & & 3.87 & \\
\hline & & & \multicolumn{3}{|c|}{ Removal percentage } & $98.09 \%$ & \\
\hline
\end{tabular}

$\mathrm{Wh} / \mathrm{m}^{2}=$ watt hour/ square meter

${ }^{*} \mathrm{~L} / 1 \mathrm{~min}=$ liter/ minute

$* \mathrm{~L} / \mathrm{h}=$ liter/ hour

$* \mathrm{EC}=($ Electric Conduction Coefficient $)=\mathrm{mhos} / \mathrm{cm}$

508

Vol. (50); Iss. (11); No.(7); Nov. 2021

ISSN $1110-0826$

ONLINE ISSN $2636-3178$ 
Journal of Environmental Sciences (JES)

Faculty of Graduate Studies and Environmental Research, Ain Shams University

El-Sharkawy et al.

The treatment was carried out at Cairo at latitude 30, during the month of April and the average solar radiation was $650 \mathrm{wh} / \mathrm{m}^{2}$, as well as the amount of water produced from the treatment procedure was calculated by using the economic type and through mathematical equations. The amount of water was recorded in the first minute of operation at a temperature $294^{\circ} \mathrm{C}$ was 6.9 liter. After one electric conduction hour, it was 414 liters and in the end of the day, after 10 hour it was 4140 liters.

According to Table (3), The water of Mediterranean Sea - Alexandria considered to be highly saline water. The Total concentration of salts was $33920 \mathrm{mg} \mathrm{L}^{-1}$ and Electric Conduction (EC) 55 The process of treatment on this sample using solar thermal technology was the result of the process of salt removal to $96.9 \%$ as the total concentration of salts has decreased to 1036 $\mathrm{mg} \mathrm{L}^{-1}$, and the electrical conductivity coefficient decreased to $1.62 \mathrm{It}$ is also noted that sodium cation decreased to $98 \%$, before the treatment was 445.76 $\mathrm{mg} \mathrm{l}^{-1}$ and then became $8.88 \mathrm{mg} \mathrm{l}^{-1}$. 
Journal of Environmental Sciences (JES)

Faculty of Graduate Studies and Environmental Research, Ain Shams University

El-Sharkawy et al.

Table (4): Water desalination analyses in Red Sea in Ain Sokhna - June 2019

$-1.5 \mathrm{~L}$

\begin{tabular}{|c|c|c|c|c|c|c|c|}
\hline \multicolumn{8}{|c|}{ Quantity of producing water } \\
\hline Latitude & $\begin{array}{c}\text { Solar } \\
\text { radiation } \\
\mathrm{Wh} / \mathrm{m}^{2} \\
\end{array}$ & $\begin{array}{c}\text { Useful } \\
\text { energy } \\
\text { w }\end{array}$ & $\begin{array}{c}\text { Exit } \\
\text { temperature } \\
\mathrm{C}^{\circ} \\
\end{array}$ & $\begin{array}{c}\text { Water } \\
\text { production } \\
\mathrm{L} / 1 \mathrm{~m}\end{array}$ & $\begin{array}{c}\text { Water } \\
\text { production } \\
\mathrm{L} / 1 \mathrm{~h}\end{array}$ & $\begin{array}{c}\text { Water } \\
\text { production } \\
\mathrm{L} / 5 \mathrm{~h}\end{array}$ & $\begin{array}{c}\text { Water } \\
\text { production } \\
\mathrm{L} / 10 \mathrm{~h}\end{array}$ \\
\hline 30 & 750 & 38353 & 309 & 7.5 & 450 & 2250 & 4500 \\
\hline \multicolumn{8}{|c|}{ Water desalination analyses } \\
\hline & & & \multicolumn{2}{|c|}{ Before } & \multicolumn{3}{|c|}{ After } \\
\hline $\mathrm{EC}($ & $\left(\mathrm{ds} \mathrm{m}^{-1}\right)$ & & \multicolumn{2}{|c|}{57} & \multicolumn{3}{|c|}{1.02} \\
\hline \multicolumn{3}{|c|}{$\mathrm{mg} \mathrm{L}^{-1}$} & \multicolumn{2}{|c|}{36480} & \multicolumn{3}{|c|}{652.8} \\
\hline \multicolumn{3}{|c|}{ Removal percentage } & \multicolumn{5}{|c|}{$98.2 \%$} \\
\hline \multirow{8}{*}{ 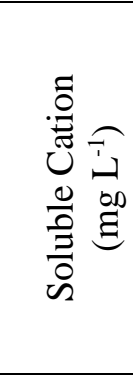 } & \multirow{2}{*}{\multicolumn{2}{|c|}{$\mathrm{Ca}^{2-}$}} & 7.69 & & & 0.2 & \\
\hline & & & \multicolumn{5}{|c|}{ Removal percentage $97.39 \%$} \\
\hline & \multirow{2}{*}{\multicolumn{2}{|c|}{$\mathrm{Mg}^{2-}$}} & 4.6 & & & 0.1 & \\
\hline & & & \multicolumn{5}{|c|}{ Removal percentage $97.83 \%$} \\
\hline & \multirow{2}{*}{\multicolumn{2}{|c|}{$\mathrm{Na}^{+}$}} & 803. & & & 9.88 & \\
\hline & & & \multicolumn{5}{|c|}{ Removal percentage $98.77 \%$} \\
\hline & \multirow{2}{*}{\multicolumn{2}{|c|}{$\mathrm{K}^{+}$}} & 5.7 & & & 0.02 & \\
\hline & & & \multicolumn{5}{|c|}{ Removal percentage $99.64 \%$} \\
\hline \multirow{6}{*}{ 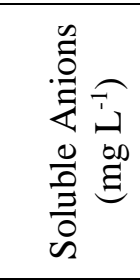 } & \multirow{2}{*}{\multicolumn{2}{|c|}{$\mathrm{HCO}_{3}^{-}$}} & \multicolumn{2}{|c|}{1.75} & \multicolumn{3}{|c|}{$\begin{array}{r}0.94 \\
\end{array}$} \\
\hline & & & \multicolumn{5}{|c|}{ Removal percentage $\quad 46.28 \%$} \\
\hline & \multirow{2}{*}{\multicolumn{2}{|c|}{$\mathrm{CL}^{-}$}} & 574. & & & 6.48 & \\
\hline & & & \multicolumn{5}{|c|}{ Removal percentage $98.87 \%$} \\
\hline & \multirow{2}{*}{\multicolumn{2}{|c|}{$\mathrm{SO}_{4}^{-}$}} & 246. & & & 2.78 & \\
\hline & & & \multicolumn{5}{|c|}{ Removal percentage $98.87 \%$} \\
\hline
\end{tabular}

$\mathrm{Wh} / \mathrm{m}^{2}=$ watt hour/ square meter

*L/ 1 min = liter/ minute

$* \mathrm{~L} / \mathrm{h}=$ liter/ hour

$* \mathrm{EC}=($ Electric Conduction Coefficient $)=\operatorname{mhos} / \mathrm{cm}$ 
Journal of Environmental Sciences (JES)

Faculty of Graduate Studies and Environmental Research, Ain Shams University

El-Sharkawy et al.

The treatment was carried out in Cairo at latitude 30, during the month of June where the average solar radiation was $750 \mathrm{wh} / \mathrm{m}^{2}$ in June, as well as the amount of water produced from the treatment procedure was calculated by using the economic type and through mathematical equations, the amount of water was recorded in the first minute of operation at a temperature $309^{\circ} \mathrm{C}$ was 7.5 liter after 1 hour was 450 liters and in the end of day after 10 hour it was 4500 liters.

According to Table (4), the water of Red sea- Ain Sokhna considered to be highly saline water. The Total concentration of salts was $36480 \mathrm{mg} \mathrm{L}^{-1}$ and the electric conduction coefficient (EC) 57. The process of treatment on this sample using solar thermal technology was the result of the process of salt removal to $98.2 \%$ as the total concentration of salts has decreased to $652 \mathrm{mg}$ $\mathrm{L}^{-1}$, which is non-saline water and the electrical conductivity coefficient decreased to (EC) 1.02 It is also noted that sodium cation decreased to $98.7 \%$, before the treatment was $803.49 \mathrm{mg} \mathrm{l}^{-1}$ and then became $9.88 \mathrm{mg}^{-1}$.

Production of green fodder from cultured barley: The water obtained from the economic model can be used in the production of green fodder from cultured barley as follows:

Through the data taken from Atlas of Egypt for solar radiation the estimated average amount of water produced for 12 months: 
Faculty of Graduate Studies and Environmental Research, Ain Shams University

El-Sharkawy et al.

Table (5): Average annual water production using the economic model

\begin{tabular}{|c|c|c|c|c|}
\hline Month & $\begin{array}{c}\text { Average solar } \\
\text { radiation } \\
\mathbf{W h} / \mathbf{~ m}^{\mathbf{2}}\end{array}$ & $\begin{array}{c}\text { Useful energy } \\
\mathbf{w}\end{array}$ & $\begin{array}{c}\text { Exit } \\
\text { temperature } \\
\mathbf{}^{\mathbf{C}}\end{array}$ & $\begin{array}{c}\text { Water } \\
\mathbf{L} / \mathbf{d}\end{array}$ \\
\hline \hline January & 250 & 7663 & 238 & 2520 \\
\hline February & 300 & 7663 & 238 & 2600 \\
\hline March & 400 & 16870 & 259 & 3100 \\
\hline April & 450 & 19939 & 266 & 3240 \\
\hline May & 600 & 29146 & 287 & 3890 \\
\hline June & 750 & 38353 & 309 & 4500 \\
\hline July & 750 & 38353 & 309 & 4500 \\
\hline August & 700 & 35284 & 302 & 4360 \\
\hline September & 600 & 29146 & 287 & 3890 \\
\hline October & 450 & 19939 & 266 & 3240 \\
\hline November & 250 & 250 & 238 & 2520 \\
\hline December & 250 & 250 & 238 & 2520 \\
\hline
\end{tabular}

Water obtained from the economic model can be used in the production of green fodder from cultured barley as follows:

The green fodder from cultured barley has a preference over dry fodder due to its high protein content and ease of digestion, and consequently, it increased the weight of sheep by $17 \%$ (El habib et al., 2019). 
El-Sharkawy et al.

Table (6): Economic profit from the project

\begin{tabular}{|c|c|c|c|c|c||}
\hline Month & $\begin{array}{c}\text { Water } \\
\mathbf{m}^{\mathbf{3}} / \mathbf{D}\end{array}$ & $\begin{array}{c}\text { Water } \\
\mathbf{m}^{\mathbf{3}} / \mathbf{7 D}\end{array}$ & $\begin{array}{c}\text { Fodder } \\
\mathbf{T} / \mathbf{7 D}\end{array}$ & $\begin{array}{c}\text { Fodder } \\
\mathbf{T} / \mathbf{4} \text { Weeks }\end{array}$ & $\begin{array}{c}\text { Price } \\
\mathbf{E P}\end{array}$ \\
\hline January & 2.52 & 17.64 & 44.1 & 176.4 & 70560 \\
\hline February & 2.6 & 18.2 & 45.5 & 182 & 70800 \\
\hline March & 3.1 & 21.7 & 54.2 & 217 & 86800 \\
\hline April & 3.24 & 22.68 & 56.7 & 226.8 & 90720 \\
\hline May & 3.89 & 27.23 & 68 & 272 & 108800 \\
\hline June & 4.5 & 31.5 & 78.7 & 315 & 126000 \\
\hline July & 4.5 & 31.5 & 78.7 & 315 & 126000 \\
\hline August & 4.36 & 30.5 & 76.25 & 305 & 122000 \\
\hline September & 3.89 & 27.23 & 68 & 272 & 108800 \\
\hline October & 3.24 & 22.68 & 56.7 & 226.8 & 90720 \\
\hline November & 2.52 & 17.64 & 44.1 & 176.4 & 70560 \\
\hline December & 2.52 & 17.64 & 44.1 & 176.4 & 70560 \\
\hline \multicolumn{7}{|c|}{ Total } & 2634 & 1053600 \\
\hline
\end{tabular}

$* \mathrm{~m} 3 / \mathrm{D}=$ cubic meters $/$ day

$* \mathrm{~m}^{3} / 7 \mathrm{D}=$ cubic meters/ 7 day

$* \mathrm{~T} / 7 \mathrm{D}=$ ton $/ 7$ day

* $\mathrm{T} / 4$ Weeks $=$ ton $/ 4$ weeks

*EP $=$ Egyptian pounds

Studies have proven that the amount of water needed to produce one Ton of green fodder from cultured barley is 400 Liters of water every 7 Days (Safina, 2018). According to Table 6, the average amount of water that can be obtained during a week of July is 31.5 cubic meters, 78.7 Tons of cultured barley can be produced using this amount. With the repetition of this cycle 4 times during one month, the total amount of cultured barley during the whole month (July) is 315 Tons on average. The price of green fodder in the local market for the year 2020/2021 is 400 Egyptian pounds, and therefore the 
Journal of Environmental Sciences (JES)

Faculty of Graduate Studies and Environmental Research, Ain Shams University

El-Sharkawy et al.

financial return during the whole month (July) will be 126 thousand Egyptian pounds.

The operating cost of the parabolic trough is zero because the inputs to the production process are renewable resources (solar radiation and salty water).

\section{REFERENCES}

Black, C. A. (1965): Methods of Soil Analysis. Soil Sci. Soc. of America., Inc Pub. Madison, Wisconsin, USA.

Duffie, J. A.; Beckman, W. A., and McGowan, J. (2013): Solar Engineering of Thermal Processes. John Wiley \& Sons, Inc., Hoboken, New Jersey Published simultaneously in Canada.

Dakkak, A. (2020): Egypt's Water Crisis - Recipe for Disasterhttps://www.ecomena.org/egypt-water/

Eaton, A. D.; Clesceri, L. S. and Greenberg, A. E. (1995): Standard methods for the examination of water and wastewater. $19^{\text {th }}$ ed. Am. Pub. Control Fed., Washington,D.C.: , American Public Health

El Habib, A.; Eladyainy, B.; Bazalo, M.; Zedan, K.; Elmarzoky, H. and Mazlom, K. (2019): Barley culture in growth chambers compared to green alfalfa and its effect On meat productivity and sex hormones in domestic sheep. Arab Journal of Agricultural Sciences, 2(2):1-14.

FAO. (1992): The use of saline waters for crop production, pp: 7-8.

Jackson, M. L. (1967): Soil Chemical Anylysis. Prentice-Hall, Inc N. J. USA.

Kalogirou, S. A. (2014): Learn more about parabolic trough collector Industrial Process Heat, Chemistry Ap- plications, and Solar Dryers. Comprehensive Renewable Energy, pp:6. 
Journal of Environmental Sciences (JES)

Faculty of Graduate Studies and Environmental Research, Ain Shams University

El-Sharkawy et al.

Lenert, A.; Nam, Y. and Wang, E. (2012): Heat Transfer Fluids. Annual Review of Heat Transfer 15, 2012.

STDF. (2017): Egyptian Atlas for Surface Solar Irradiation. ISBN(9032/2017)

Singh, R.; Chandra, Y. P. and Kumar, S. (2017): Computational and parametric analysis of parabolic trough collector with different heat transfer fluids. Advances in Intelligent Systems and Computing, 547, 321-331.

Safina, S. (2018): Production of cultured barley. April, 35. https://www.researchgate.net/publication/324676860.

United States department of Agriculture (1969): Diagnosis and Improvement of Saline and Alkali Soil. U.S. Salinity Laboratory Staff, Handbook $2^{\text {nd }}$ ED., 60. USA. 


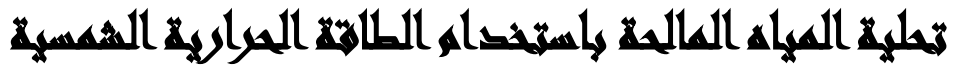

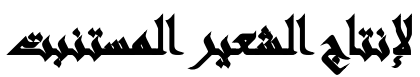

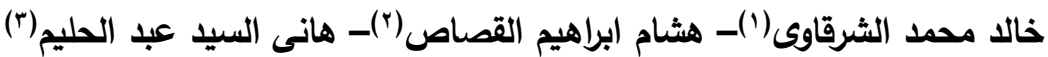

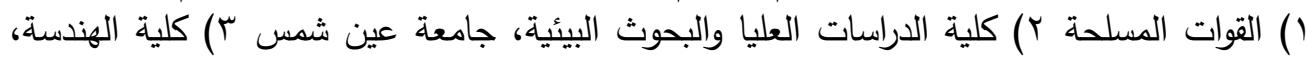
جامعة عين شمس

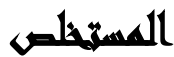

في العقود الماضية عانى المزيد والمزيد من البلدان من مشاكل ندرة المياه، فكان هناك ضران ضرورة

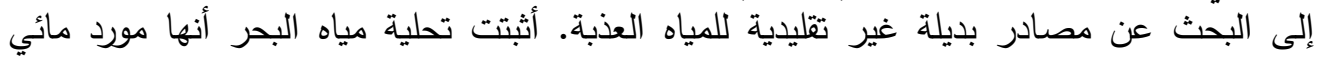
موثوق به ومستدام إقتصاديًا منذ النصف الثاني من القرن العشرين. المجمع الثمسي القياه القطع المكافئ

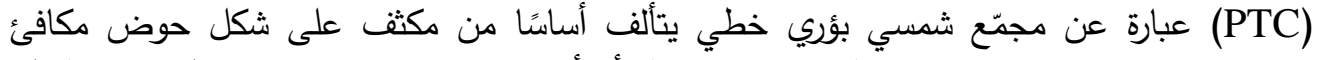

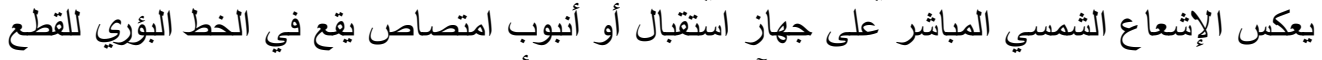

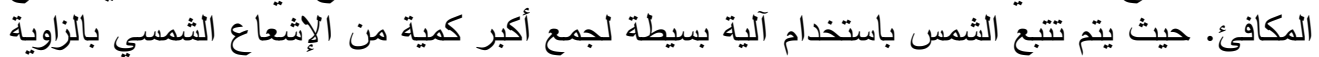

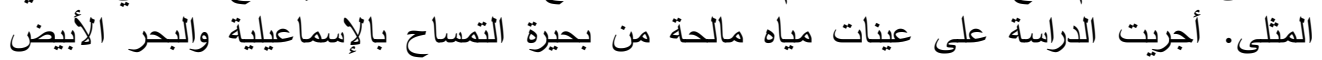

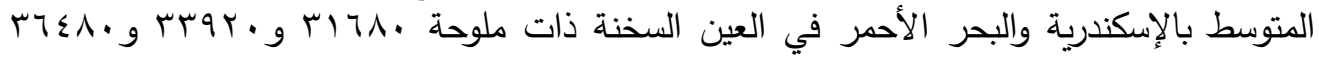

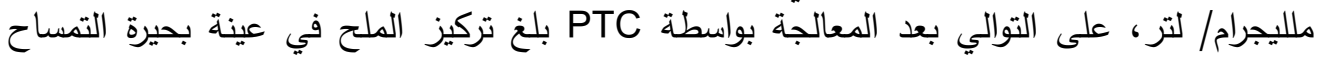

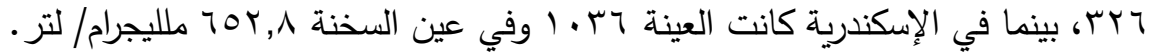

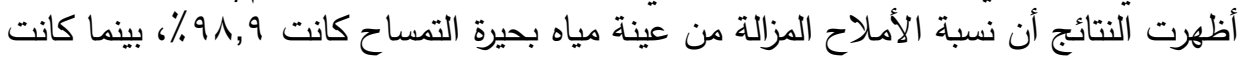

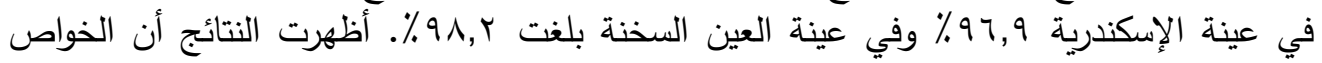

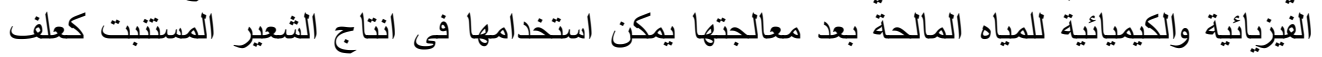

